\title{
Domestic Slaughter in Southern Italy, with special reference to Campania Region
}

\author{
Ottavio Soppelsa ${ }^{1, *}$ and Chiara di Martino ${ }^{1}$
}

\begin{abstract}
The relationships between animals and humans date back thousands of years. Cultures around the world developed specific ways of interacting with the fauna over time, so that human communities accumulated a huge deposit of animal knowledge closely integrated with many other anthropological aspects focused on the human-animal relationship. Through the administration of a questionnaire-interview, in this work we studied ritual aspects related to animal slaughter, as well as the link between the slaughterhouse and the time of the year. Moreover, the apotropaic uses of Bos taurus Linnaeus, 1758 and Sus scrofa domesticus Erxleben, 1777 , by local rural communities, were analyzed. The data we collected come with important witnesses, supported by old pictures and tools used during the slaughter that reinforced the story of the interviewee, allowing to draw a timeline after which the relationship between man and farm animals moves and gets modified. These almost forgotten rituals constitute an important ethnozoological knowledge to be integrated into our human cultural heritage. To the best of our data, this is the first study documenting the apotropaic uses of Bos taurus Linnaeus, 1758 and Sus scrofa domesticus Erxleben, 1777. All the questionnaires, administered in Campania, were analyzed and compared in the search of ritual customs, archaic beliefs and ancient legacies still present today and inherited from elder times. Rites surrounding animal slaughter aimed at communicating with the divine and at explaining all those processes that cannot be readily answered. Man, by making animals the protagonists of mythological tales and investing them with a sacred force, has linked to the slaughtering act a psychological component that has led the killing itself to being configured as a ritual. From the witnesses gathered, interesting parallelisms emerged stimulating thoughts on a serious and complex dichotomy of our present-day society: a meat-based diet versus the total rejection of it. Integrating scientific knowledge with local ecological ones, the data collected in this work can be used to design an effective and targeted conservation management strategy for these mammals as valid alternative to intensive farming.
\end{abstract}

Keywords: Slaughter; Livestock Holding; Rural Conservation 


\section{SIGNIFICANCE STATEMENT}

This work represents a first contribution on the domestic slaughtering techniques of breeding animals. The main contribution of the manuscript is to put some light on the relationships between traditional societies and their farm animals. The links established between the two parts are analyzed under two fundamental aspects: the slaughter itself, an act to be performed at home and from which sustenance and economic integration are obtained, and, on a different plane, the private and sometimes secret sphere of fascination. These two aspects intersect with each other in a charming and somehow mysterious way and must be preserved as part of the biocultural heritage of the local communities. The field investigation highlighted the survival of ancient customs and rituals dating back to Magna Grecia.

\section{INTRODUCTION}

The variety of interactions (both past and present) that human cultures establish with animals is the subject of ethnozoology (Alves and Souto 2015). To embrace the complexity of human relationships with the environment, scientific knowledge must be integrated with local ecological and anthropological awareness. This is the first study on the slaughter and fascination of animals in the Campania region conducted from an ethnozoological perspective in a multidisciplinary framework. The study of local peoples is of pivotal importance to preserve biological, cultural and linguistic diversity, which represents the biocultural heritage of local communities, worth to be preserved and transferred to future generations. Sus scrofa domesticus Erxleben, 1777 and Bos taurus Linnaeus, 1758 , have always been a fundamental food resource. In ancient times their slaughter always included implications of a sacrificial ritual, through which a communication was established with the deities (Bremmer 2008; Labarbe 1984; Scarpi 1993), the creation of the cosmos was explained (Lincoln 1975) or social structures were reproduced (Goody 1982; Nadel 1970).

By analyzing these points, we notice that, although the sacrifice has taken on different nuances over time, it has always been an essential act of union of human beings among themselves and with the deities (Smith 1889). According to Bremmer (2008), for the Greeks, if prayer and divination were also important for communicating with divinities, there is no doubt that the most important way of communicating with the divine was the sacrifice. In Greek culture (as in various others), indeed through the sacrificial banquet, human beings encountered the deities, whom were offered some victim's parts, generally the leftovers. Frazer (1894), referring to a different culture, reports: "Lapps [...] laid the bones and the rest in anatomical order in a coffin and buried them with the usual rites, believing that the god to whom the animal was sacrificed would re-clothe the bones with flesh".

Why do gods, in the Greek sacrifice, should get satisfied with bones and skin? According to Vernant "Getting pleased by bones' smoke, living with odors and perfumes, the gods witness to belong to a race whose nature is completely different from men's one. They are the immortals, who live forever, young forever, whose being does not involve anything perishing and who have no contact with the dominion of the corruptible" (Vernant 1987).

The Greek rituals involving the immolation

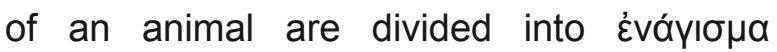


(enágisma) or aípaxoupía (haimakouría) sacrifice of one or more animals to the dead, to the heroes, to the chthonic deities. Generally, the sacrificial victim was entirely burned - and Ouoía (thysía) - sacrifice of one or more animals destined for the gods of Olympus; only the fat and the bones were burnt, the rest was slaughtered, cooked and distributed in the sacrificial banquet (Bremmer 2008; Scarpi 1993 and 1994). According to Greek culture, the edible parts of the victim were distributed to the guests and consumed boiled or roasted (Leguilloux 1999; Van Straten 1995), because eating the meat after cooking elevated the men to a higher stage than the animals, feeding on raw meat (Vernant 1981).

The roasting concerned some innards,

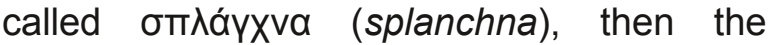
boiling of the remaining parts of the animal, бápł (sarx), took place in a metal cauldron, $\lambda \varepsilon \dot{\beta} \eta$ s (lebes, Figure 1), with a rounded bottom (Aristotle 674 to 4-6).
The sacrifice role is also fundamental to reproduce social structures and hierarchies (Goody 1982; Lienhardt 1961; Nadel 1970). This is the case of societies like that of the Dinka (South Sudan), in which the social structure is reproduced by distributing portions of different cuts of meat, or of tribes like that of the Gonja (Ghana), where the sacrifice is almost totally devoid of any religious value. Ritual serves to simultaneously achieve social integrity and respect for the hierarchy, as well as reaffirmation of the latter: the members of the Gonja tribe eat the same kind of food together, but they do not eat it at the same time (Goody 1982). It is a way of reconfirmation of the group membership, employed for the creation of the society, by establishing a strong link between people who consume a meal together (Lincoln 1975). The value attributed to the sacrificial moment within the previously mentioned societies is tinged with political tones, as

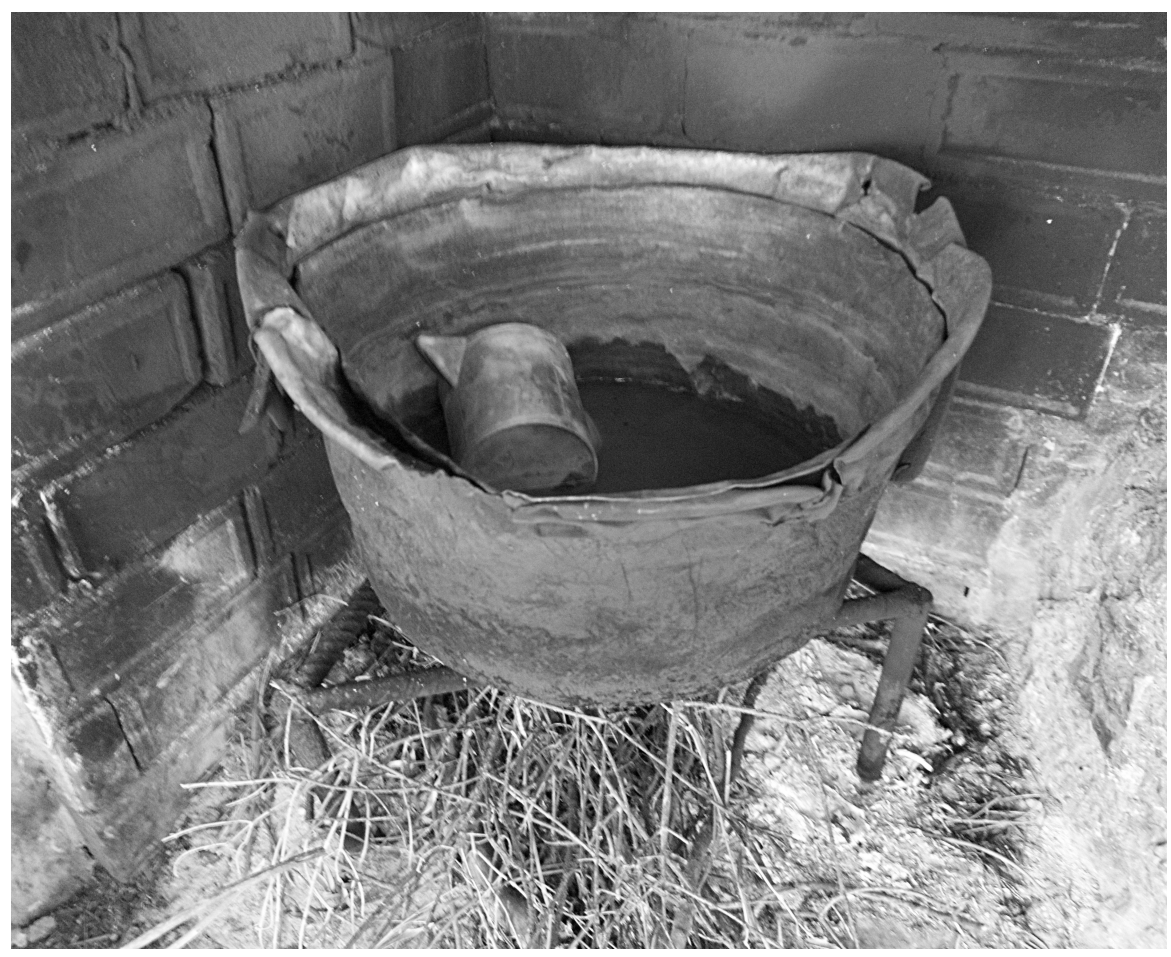

Figure 1. Iron cauldron, a large pot used to boil water to be thrown on the pig, in order to facilitate the removal of hairs; noticeable the similarity to the ancient lebes. (Photo by the authors) 
taking part to the food distribution means a continuous renewal of society.

We cannot omit here the reference to the Sublime Society of Beef Steaks, in which the members, made equal by the common plate, left social differences outside the circle (Walter 1871).

In a broader sense, animal killing would reproduce the creation of the cosmos (Cattabiani 2008; Lincoln 1975; Lincoln and Baiocchi 1984); for example, for Mithraism tauroctony represents the allegory of the birth of the cosmos, of the creation of life, which manifests itself through the primitive sacrifice of a bull (Cattabiani 2008). Another ancient story, relating to cosmogony and proto-Indo-European sociogony, says that the first priest (Manu, man) would have sacrificed the first king, his brother (Yemo, twin), along with the first bull specimen. This sacrifice gave birth to the world (Lincoln 1975; Lincoln and Baiocchi 1984).

This research has as its objective a study on the customs and practices still used in Southern Italy during the slaughter of animals, to investigate possible relationships with ancient sacrificial practices. We intend to verify the possible survival of the sacrifices and their anthropological function. In addition, we will study the current practices of domestic slaughter to untangle the most complex aspects by studying the customs and uses related to breeding and slaughter, typical of the agricultural world.

\section{MATERIAL AND METHODS}

This work was carried out according to the ISE code. The sample survey was prepared and administered in accordance with the rules of the experimental method, allowing, by doing so, to extend and generalize the results obtained on the population's sample. To ensure data quality, the study was conducted on a probabilistic sample. This sampling method ensures that all the members of the population have an equal probability of being included in the sample, and, therefore, the latter represents a miniaturized version of the target population. The sample is therefore representative of the population as its characteristics reflect the distribution observed in the whole population (age, education, etc.).

The data collection tool was a questionnaire-interview that took place face to face so as to employ also the visual channel as a method of communication (Zammuner 1998).

The survey was carried out by asking the questions to the interviewees by reading them directly from the specially prepared questionnaire and in paper form. The motivation of informants to take the survey is known to have a great influence on the results: those who show interest certainly make it easier to obtain the answers. On the other hand, other subjects (such as the elderly and those who show greater difficulties in expressing and communicating) may not be particularly interested in investigations, therefore requiring more solicitations to responses. Of course, any solicitation was always carried in a careful manner in order not to suggest possible answers and respecting the privacy of the interviewees.

The interviewer who, before administration, explains that the time required is relatively short, thus minimizing the interviewee's loads, usually completes the interview-questionnaire. On the other hand, in order to properly carry out the interview, if the subject uses his time also to narrate anecdotes not strictly related to the questions raised, the interviewer granted him/ her the necessary attention in order to offer 
a "reward". The interviews were also structured anonymously so as not to jeopardize the truthfulness of the answers.

The questions composing the questionnaire have been standardized to expose the informants to the same inputs (Manganelli Rattazzi 1994) and were arranged so that the items were proposed in a logical order and subdivided by topic.

The questions were formulated as short as possible and contained a maximum of twenty-five words each (Payne 1951). This general rule may be subject to exceptions if the interviewee requiring greater clarity (Bradburn 1983). For interviews administered to subjects who no longer raised animals, or who had lived in a rural context only earlier in their lives, the questions were supported by more explanatory phrases, so that the subject had time and material enough to focus attention to the topic dealt with. Above all, open-ended questions were used to allow responders to reply using the terms and vocabulary that belong to their background (know-how); such questions, moreover, are more convenient when dealing with sensitive and/ or personal topics (Bradburn and Sudman 1979).

Open-ended questions (i.e. "How did the animal grow?") also have the advantage of giving the interviewee the time necessary to gather, reorganize and expose ideas calmly.

Closed-ended questions (or multiple ones) were used, instead, for very few items (i.e. "The killing of the animal takes place: morning; afternoon; evening"). For some of them, the responder was able to reply first according to a dichotomous modality "yes/ no" (i.e. "In the past, the number of farm animals per family was lower than today?"). And, if necessary, he was asked to provide more data by submitting a further question (i.e. "If so, did this entail a different way of conceiving birth or killing?").

In the formulation of the questions, technical and specialized terms were avoided so not to create a gap between the interviewee and the interviewer or cause embarrassment (Moser and Kalton 1977); on the other hand, it was fundamental to avoid a dialectal language, preferring a simple but formal interaction (Bailey 1978).

According to Dautriat (1970), the simplest and most immediate questions were inserted at the beginning of the questionnaire (i.e. "What kind of animal are you breeding?") while the last section was dedicated to the most intimate questions or that could arouse more hostility (i.e. "The moment of sacrifice involves the recitation of some particular phrase?").

In the same way, generic questions were also asked first, while those requiring more detailed answers and a considerable effort of memory were placed at the end of the questionnaire, so that the subjects had sufficient time to go psychologically inside of the topic treated.

Among the data requested from the interviewee at the end of the questionnaire, there were birth date and the level of formal education received, both being fundamental tools for placing data in the right context and allowing to highlight and follow any differences in the relationship with the animals, due to generational and/or cultural changes.

Each questionnaire was provided with an identification code guaranteeing the anonymity of the interviewee but also a correct classification of the data obtained: the questionnaires showed a code, placed in the upper right corner above each sheet, which facilitated the digitization process. Processing and analysis were carried out with Excel and Word software programs ( $v$. 16.11.1). The Excel software (Microsoft 
Corporation, USA) has been used to collect records in a database; statistical analyses were used to identify data with a low frequency.

\section{RESULTS AND DISCUSSION}

The questionnaires were administered in the provinces of Naples, Salerno and Avellino. The study highlighted the presence of cultural aspects and attitudes shared by almost all interviewees. The species found are listed in Table 1.

Table 1. Species found during investigations.

\begin{tabular}{lll}
\hline Scientific name & Common name & Neapolitan name \\
\hline Bos taurus Linnaeus, 1758 & ox, cow & voie, vacca \\
Sus scrofa domesticus Erxleben, 1777 & pig & puorco \\
Sus scrofa Linnaeus, 1758 & wild boar & puorco sarvateco \\
Oryctolagus cuniculus (Linnaeus, 1758) & rabbit & cuniglio \\
Capra hircus Linnaeus, 1758 & goat & zimmaro, crapa \\
Ovis aries Linnaeus, 1758 & sheep & pecora \\
Numida meleagris (Linnaeus, 1758) & guinea fowl & gallina turchesca \\
Meleagris gallopavo Linnaeus, 1758 & turkey & tacchino \\
Gallus gallus (Linnaeus, 1758) & chicken & pullasto \\
Anser anser (Linnaeus, 1758) & goose & papara guardiana \\
Columba livia Gmelin, 1789 & pigeon & palummo
\end{tabular}

carried out since ancient times: the jugulation, i.e., a cut inflicted to the jugular, which is carried out by a knife called scannapuorco in dialect (Figure 2 and 3 ).

The practice of pig slaughtering at home is subject to the EC 852/2004, legislation establishing the Hazard-Analysis and Critical Control Points (HACCP).

Interviewed people are aware that the above-mentioned regulations on pig slaughter require a veterinarian to sample the liver for analyses. In fact, they said: "If meat is good you keep the pig, if not, he takes the pig away!" (DF, Gragnano, NA); "The vet must come and take a sample of meat when we slaugter the pig, to see if it's ok" (FL, San Gregorio Magno, SA).
It emerged that ritual practices, charms and beliefs gravitate almost exclusively around the pig and the cow: the data collected on other animals mainly concern the methods of preparing meat. It is likely that, rituals focus on large animals because their meat feeds the whole family longer.

\section{Sus scrofa domesticus Erxleben, 1777}

The present-day pig slaughtering technique is the same which has been
However, a large proportion of the sample interviewed openly says they do trust the professional involved in the inspection, because "the vet can also say that the meat is not good, although it is, to keep the whole pig!" (GA, Cervinara, AV). Some subjects, therefore, opt for a different approach to the situation: "You give a tray full of meat to the vet and you keep him quiet!" (DL, Gragnano).

Pig slaughter involves various ritual practices widely shared by the interviewees; for example, interviewees report that it is forbidden to engage in marital relations the night before the pig is processed, to avoid losing meat: "Women, if they had marital relations the night before the slaughtering, 


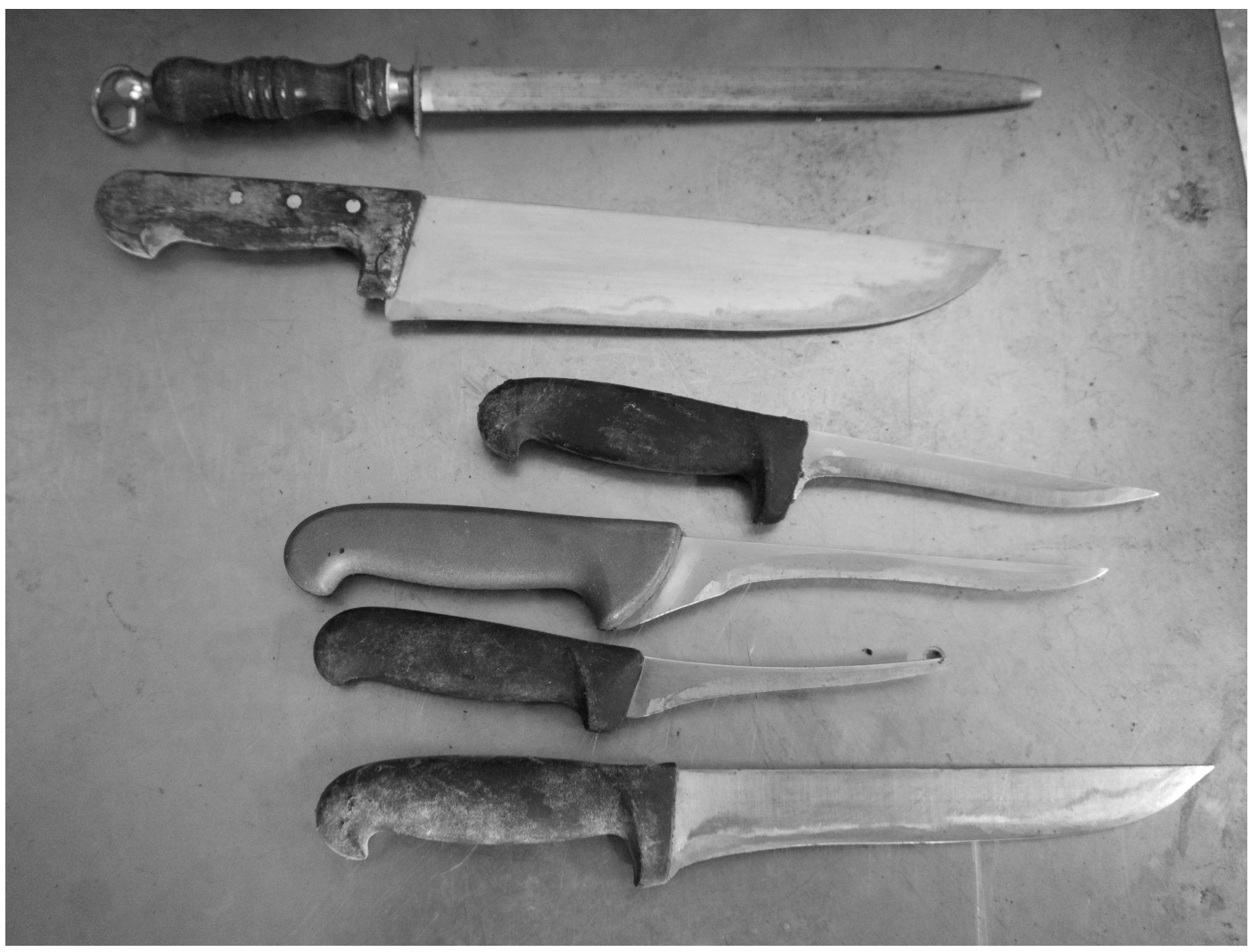

Figure 2. Knives used for pig slaughter. The first tool from the top, called acciaino, is used to sharpen the blades; the second one to divide the meat; the third to cut the ham; the fourth, called scannapuorco, is used for the jugulation; the fifth to remove the meat from the bone and the last to remove the lard from the pork rinds as well as to remove the hairs from the pig's skin. (Photo by the authors).

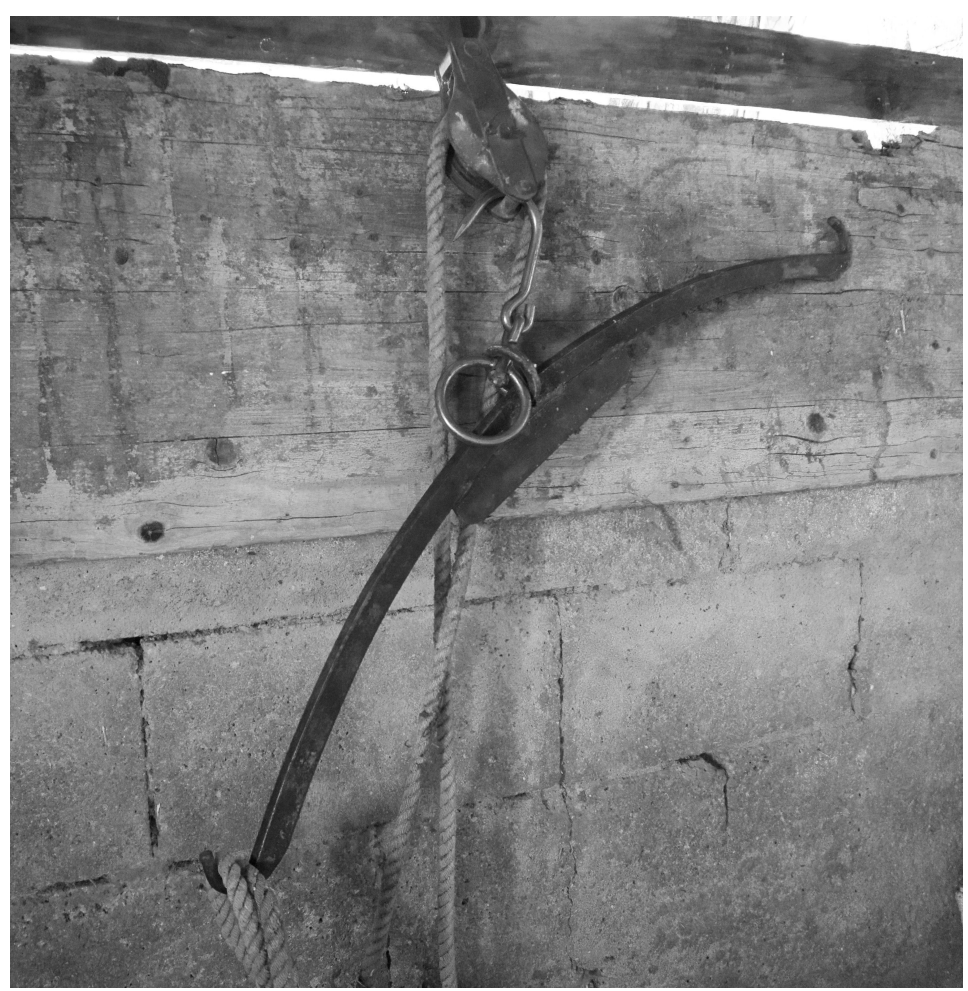

Figure 3. Wooden cossale, a tool used to raise the pig up during and after jugulation. (Photo by the authors) 
cannot touch the pig" (AC, Pimonte, NA); "The night before the pig is killed, wife and husband cannot have sex" (IA, Scafati, SA); "If a woman has menses and has sex with her husband, then the husband cannot make sausages or he will lose everything" (GA, Cervinara).

Other interesting cultural practices take place if a death has occurred in the family commissioning the pig slaughter. The butcher cannot offer condolences to the family of the deceased because the meat of the pig would rot like that of the dead: "When someone dies, if the pig has to be slaughtered, condolences cannot be made" (FL, San Gregorio Magno). In addition, if someone pays a visit to a deceased person, he/she cannot work the pig for the following forty days; if the pig had already been killed, then only those who have not seen the dead should process it. "There have been cases where the meat has gone wrong! It is said that as the dead man rots, also the pork rots!" ( $A B$, Pimonte); if one has to slaughter a pig, he/she should not offer condolences and should kill the animal in total silence if there was a mourning! "It was not a party anymore; there was a lot of respect for the whole neighborhood, so they did not take offence if someone did not offer condolences" (CF, Aurano, hamlet of Gragnano).

The precautions related to the pig slaughter also concern restrictions imposed on menstruating women: "The woman during her period cannot help processing pork" (FL, San Gregorio Magno); "Women who have their period cannot touch the pig!" ( $A B$, Pimonte); "If the woman has her period, she cannot touch the pig" (CZ, Scafati). These last two customs (i.e., the avoidance of condolences and menstruated women) have an explanation of sanitary nature: in the lack of general hygiene, contact with bacteria would irreparably contaminate the meat, especially if going to be preserved.

Pig's eyes are not greatly dissimilar to human eyes in terms of size, shape and mobility; according to popular beliefs, receiving a look, even furtive, before or during the killing would result in an explicit condemnation of the butcher to the "evil eye". To make the pig's eye (fare l'occhio del porco, Tommaseo and Bellini 1861-1879), in fact, means to look out of the corner of the eye, in secret, and such an action would sound, in the countryside, like throwing a spell of bad luck. "Looking with the eye of the pig" ("guardare con l'occhio del porco" Gherardini 1854), means to look crooked, sideways, with an evil eye. To avoid this, an ancient practice consists in throwing the pig's eyes against a ceiling (or as far as possible). This custom is also found in places distant from each other: "You have to cast the eye of the pig against the ceiling to avoid the evil eye, but not the ceiling in the inhabited house as it gets dirty, under the barn instead!" (CE, Tramonti, SA); "You have to throw the pig's eye under the ceiling not to lose the meat and take the evil eye away" (AT, San Marzano sul Sarno, SA); "We used to throw the pig's eye against the ceiling, to ward off the evil eye, when we started to process the pig!" (DF, Gragnano). This attitude has been confirmed not only in Cervinara, where the interviewee RM explained that the pig's eyes should be eaten as well because, as his grandmother said: "Of a pig, you only dump the legs of the table and the eyes of people" (DF, Gragnano). Therefore, almost all responders claim to throw the pig's eye to prevent disaster from affecting their family, without knowing that this practice is indeed very old. The Campanian writer Giovan Battista Basile (1566-1632) already mentioned the custom of throwing the pig's eye "to throw the pig's 
eye whoever it strikes" ("tira' ad uocchio de puorco, a chi coglie coglie" Basile Cunto III, 9, 19). As in the past, also today pig's owners, after slaughtering, throw the pig's eye against the ceiling of the house "as a good omen", "against the evil eye", "to avoid misfortune". However, a less likely explanation could derive from a passage by Pliny: "It is believed that the pig after losing an eye immediately dies, otherwise it lives up to 15 years, some pigs even up to twenty" (Pliny VIII, 206).

Another fundamental aspect that emerged from the interviews concerns the custom of organizing parties after the killing of the pig. The whole family takes part to the slaughter. The whole family lives it with participation, shouting "good health" at the moment of jugulation and clapping their hands to celebrate (DA, Scafati). Between January and March, the traditional period of pig slaughtering, the owners of the pig organize banquets to which butchers, friends, neighbors and relatives take part, to celebrate by eating together. The main dishes are not only pork-based: after the slaughter of the pig, it takes a few days before the sausages are prepared and the pork processing is finished (Figure 4 and 5).

This aspect of conviviality intersects perfectly with an interesting peasant ritual called spido or spito, which consists in the preparation of a tray with different cuts of pork to be distributed to neighbors and relatives. The informants say that they only had a pig for a family and when it was slaughtered, they prepared the spido, with costatelle (the pork ribs), and they were prepared in a number equal to that of the participants. So, if there were four people in a family, four pork ribs had to be prepared. The spido had to be made so that every member of the family to whom it had been brought had a piece of everything. GA
(Cervinara) says that "spido means that I will give you something and then, when you kill the pig, you will bring me something"; "If you did not, after slaughtering the only pig you had, it was over!" (AD, Pimonte); obviously, by doing so "sometimes even half a pig went away" (CF, Aurano); "Because each portion must contain blood, liver, some pork ribs...!" (EC, Tramonti). Informants say that the custom of the spido is ancient and comes from the need to obtain other meat once killed the only domestic pig. This archaic necessity has become over time an important and widespread peasant tradition. Even today, those who receive the spido have to reciprocate when they slaughter their pigs: a do ut des aimed at the wellbeing of the participants in a tacit pact. Nowadays, more than one pig is bred and meat consumption has become much more economically accessible, so the practice of spido loses the need and urgency that once characterized it and can be interpreted as a means of tightening interpersonal relationships. In fact, the spido is offered only to close relatives and neighbors, to those few privileged persons with whom you wish to maintain or consolidate good relationships.

The most recent implications of the spido practice, more than the ancestral ones may be linked, with appropriate disillusion, to a way of assessing personal value in ancient Greece: the distribution of pieces of meat stuck in a bar of metal (iron or bronze)

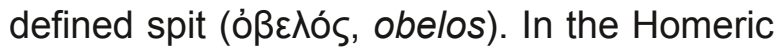
poems, the spit was the tool with which the flesh of the sacrificed victims was roasted, after the viscera, and was then distributed according to the previously established parts (Laum 1924). The spit, from an original sacrificial instrument, gradually became material of money (Laum 1924). Thus, the obelos is a precursor of the most important 


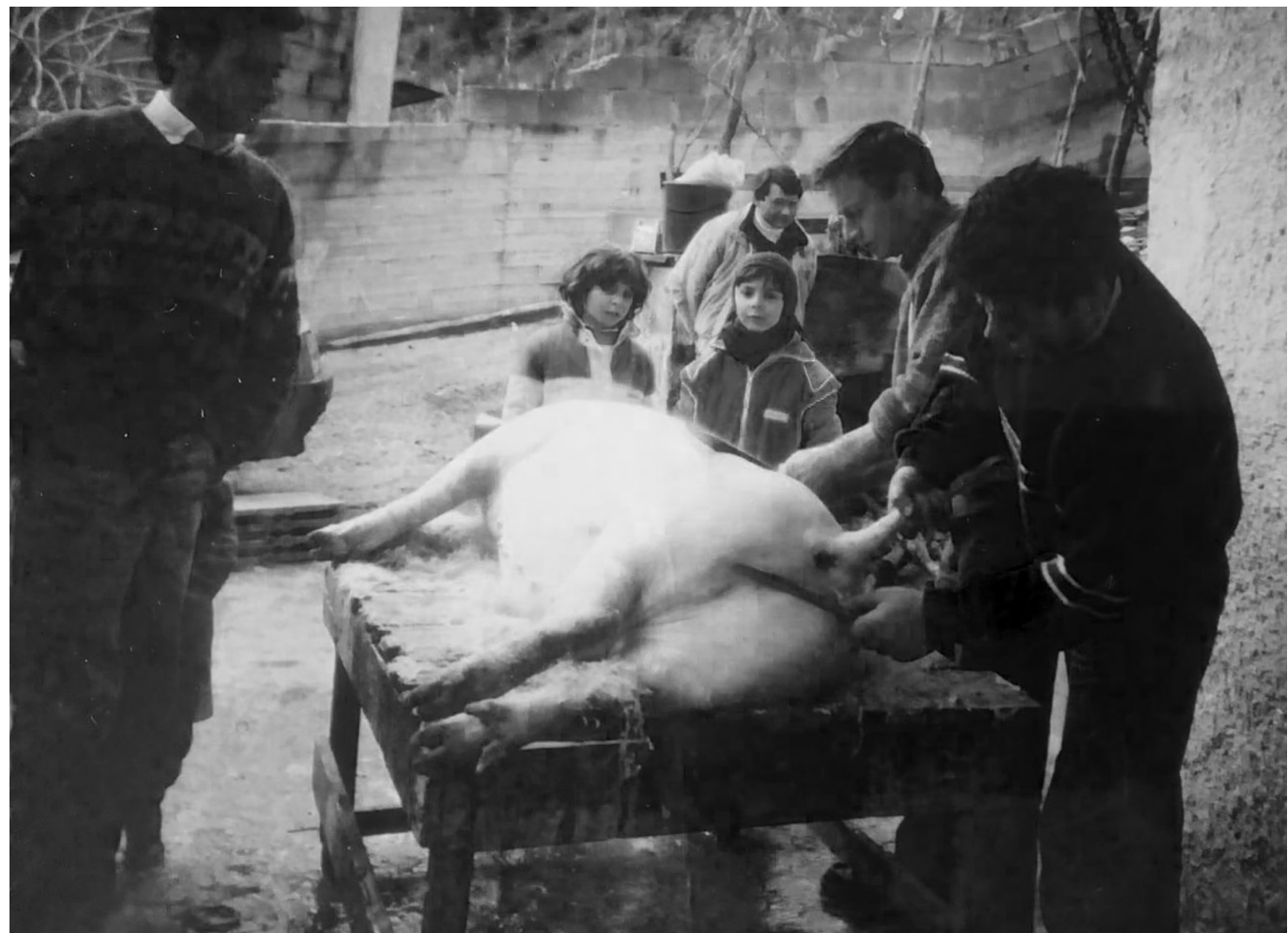

Figure 4. Removal of hairs after throwing boiling water on the pig; the hairs are removed using of a proper knife. (Photo by AC, Pimonte 1985).

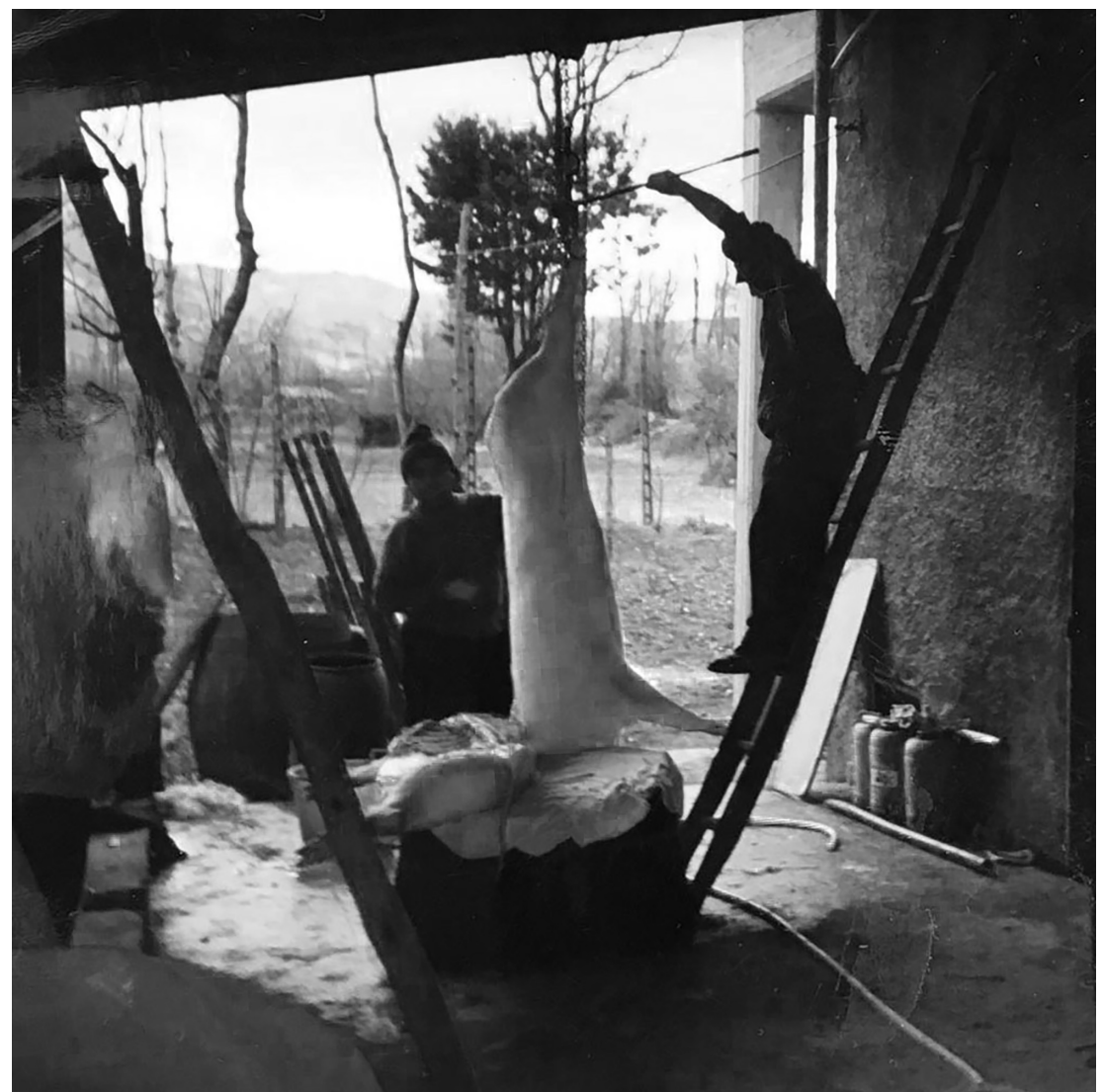

Figure 5. Pork processing: part of the pig is still hanging from the wooden cossale. (Photo bt GA, Cervinara 1998). 
Greek currency: starting from this bar of iron we obtain, by substitution, a silver coin which takes the name of óßo入ós (obolos) and which represents, once again, an object for measuring value (Parise 1984).

Besides the obvious similarity between the two terms, spit (Italian spiedo) and spido, there is also a conceptual resemblance between the first, a measure of value, and the second, a means of reconfirming interpersonal relationships, to make us lean towards the hypothesis that the modern practice of spido can derive from the Greek

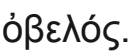

\section{Bos taurus Linnaeus, 1758}

Unlike the pig, the cow cannot be slaughtered at home: to slaughter a cow a nail gun (a captive bolt pistole) is necessary, carrying out operations in a slaughterhouse: "The slaughter of the cow in the house is just illegal!" (DM, Gragnano).

From the interviews, it emerged that many families have a special connection with their cows; in some cases, this relationship almost tends to turn into veneration and affection. CB (Aurano) remembers, with evident emotion, the tears of the mother on the day they sold the cow and the sadness that has affected the whole family. Many people consider a cow part of the family, the only animal to be given a name. According to the interviewees, the day of the cow's sale is a sad one, and the sadness is so strong as to prevail on the joy of earning money. The interviewees said: "The day they came to take the cow and brought it away I always cried" (ER, Colliano, $\mathrm{SA}$ ); "We were very fond of the cows" (DZ, Tramonti).

From the interviews it also emerges that families raised several cows (usually five or six) so that the declared affection may be interpreted also as an exasperation of the feeling of economic dependence on these animals, so essential within a farm enterprise.

The words of CB (Aurano) support this hypothesis: "The daily milk's revenue was used for the daily purchase of food". DI (Gragnano) expounds further on the role of the cow in the agricultural reality: "You have to imagine a chain, a battery of four milk cows and four calves in sequence. Entering the stable there was the animal that was about to go to the slaughterhouse, tied near the manger the six-months younger and then the little boy going around the stable and sucking milk. It was like having a mini beef industry"

In light of these considerations, it is easy to understand why cows benefit from a treatment much more refined than that offered to other animals: if a disease or a harmful occurrence affected these mammals, serious repercussions would occur on the whole family.

Since the loss of milk involves serious economic damage, the superstitious practices aimed at preventing the event certainly do not lack "we must dilute the first milk taken from the animal with water so that the cow does more milk!" (DV, Tramonti); "You must not allow strangers to enter the stable when the cow produces milk, otherwise it loses it" (AN, Scafati).

Moreover, with the first milk of the cow it is customary, in many peasant families, to make ricotta (an Italian milk derivative) to be distributed to friends and relatives (we here note a resemblance to the spido custom), but attention must be paid not to drop the milk, otherwise the cow may not produce more milk in the future and the family would then be exposed to the danger of attracting the evil eye: "With the first milk, colostrum, make a cheese and bring it to the relatives, 
taking care not to drop it, or you will attract the evil eye!" (EV, Colliano); "With the colostrum you have to make the ricotta and distribute it to the whole neighborhood and relatives for good wishes" (DV, Tramonti); "When the cow gives birth, you boil the first milk and make a ricotta, then you have to give it away because the more you give it, the more the cow will give birth; you should not give it to animals and you should not drop it or the cow will no longer produce" (AO, Bagni, hamlet of Scafati).

Moreover, cow's horns should be hung outside the house for good luck and to ward off the evil eye: "It is said that the horns of all animals bring good luck, if you hang them outside your home, they will protect your house from bad luck" (BF, Scafati); "We hung cow's horns outside home, against the evil eye" (DL, Gragnano); "The horns of the cows and the pieces must be exposed outside as a good omen. Then, when people with small eyes enter the house, we said, while throwing salt: eye and against eye, take aim, smash their eyes and get the evil eye out, tié!" (uocchie contruocchie piglia la mira, schiattale l'uocchie e fore 'e maluocchie, tié!) the latter word meaning 'at you', mimicking the gesture of the horns with the fingers (AP, Bagni). The horns, then, hung outside the houses or reproduced by raising the index and the pinkie of the hand, are considered effective against the evil eye. According to Arditi (1825), the Elder ones put the thumb between the index and the middle finger (imitating the phallus), considering, on one hand, this gesture superstitious and considering, on the other hand, this finger obscene and immoral (Arditi 1825; Elworthy 1895). It is also said fare la mano fica (to do the cunt-hand) and according to Elworthy (1895) " [...] is as an amulet against the evil eye; and the Neapolitans utter the expression, te faccio na fica, as if they would say to a friend: 'may the evil eye do you no harm!' The meaning of this gesture is identical with that of making horns in the apotropaic sense; in fact, when making this gesture they often pronounce the same sentence as they use in making horns against fascination". The ancients used the phallus against the charms, in the same way and for the same reason, as our credulous mob used to generally make use of the horn; not disdaining, at the same time, to conform the fingers of their hand like horns, in the occasions in which sees people suspected of being a jinx approaching, how they love to express themselves (Arditi 1825). Both the phallic symbol and the horn are therefore considered superstitious remedies to such an extent that in "Gio. Boccaccio novels [Italian poet, 1313-1375] horn and phallus sound the same" (Arditi 1825). The horns express strength and power, in fact many deities are often depicted with horns; the male genitals, on the other hand, have always symbolized fertility and the power of creation. Among the Egyptian deities, Isis and Hathor bear the disc with the horns of the crescent much prolonged, so as to assume the appearance of the horns of a cow. Hathor is often represented with the head of a cow on a human body, and also frequently as a cow, having the disc and horns on its head. Among the Greeks, who obtained much of their mythology from Egypt, the counterparts of Isis and Hathor were Artemis and Iö, and the latter became at length identical with Hera; all of these deities were symbolized by the Crescent (Elworthy 1895). Moreover, it is not uncommon for the gods who dispense the goods of the earth to be represented with the cornucopia in their hands. It is a symbol of fertility and is represented by a horn, which originally was that of the goat Amaltea, nurse of Jupiter, full of fruits and 
surrounded by herbs and flowers (Graves 1987). The image of the horn, over time, was then mixed with the phallic image, so much that in Naples the classic curniciello (a little red horn) used as an amulet against the evil eye, is just the stylization of the phallus of the Greek-Roman god Priapus who, according to the Priapea (Bianchini 2002), defends the gardens and fields: he, with the curved scythe and the penis painted with red crimson, threatens the thief who approaches the garden and tries to steal what the villicus has laboriously made to grow.

\section{Columba livia Gmelin, 1789}

Regarding dove, an unusual way of slaughtering has emerged: the subjects affirm, in fact, to be in the habit of drowning the animal. Upon questions, BG (Bagni) answers: "I drown doves, unlike chickens". Questioned on the reason for this unusual practice, however, cannot provide an explanation. EP (Colliano) seeks to clarify the peculiar mode of slaughter: "The dove is drowned because it is the animal of God". This slaughtering practice probably derives from the symbolism that the animal has always had over the centuries. According to Graves (1987), in the beginning, Eurynome, the Goddess of All Things, rose naked from Chaos and wheeling about, she caught hold of the north wind, rubbed it between her hands, and created the great serpent Ophion. Eurynome danced to warm herself until Ophion, grown lustful, coiled about those divine limbs and was moved to mate with her. So Eurynome was got with child. Subsequently, she took the form of a dove, and in the right period of time laid the universal egg. At her bidding, Ophion coiled seven times about this egg, until it hatched and split in two. Out tumbled all the things that exist, his children: sun, moon, planets, stars, the earth with its mountains and rivers, its trees, herbs and living creatures.

According to Pliny "the doves, the crows, the blackbirds, the partridges purge themselves every year with bay leaves" (VIII, $41,101)$. However, directly related to the Latin term laurus (laurel tree) is the Greek term Daphne ( $\Delta$ á $\varphi v \eta)$ (Beekes 2009) name used to indicate a naiad nymph associated with water, once again, a symbol of purity. Even the Christian religion has confirmed and consolidated the stereotype of candor and innocence of which $C$. livia is ambassador: the Bible narrates that Noah had a dove coming out three times from the ark, which eventually returned to him with a twig of olive tree in the beak, clear sign that reconciliation with God had taken place and the flood ended (Genesis 8:9-14). The same events reappear in the Greek variant of the flood myth: Zeus, disgusted by men, let loose a great flood on the earth meaning to wipe out the whole race of man; but Deucalion, King of Phthia, built an ark and went aboard with his wife Pyrrha. The ark floated about for nine days until, at last, the waters subsided. It is said that Deucalion was reassured, once again, by a dove, which he had sent on an exploratory flight (Graves 1987).

Following these considerations, it is very plausible that spilling the blood of an animal that has always been considered sacred, is felt as an impious and sacrilegious action to be avoided at all costs. It is therefore very likely that the custom of drowning C. livia derives from the need to combine slaughter with the moral veto to disperse the blood of this animal.

The sacrificial rituals lead the slaughter of some animals (especially pig's slaughter) to become a ritualized killing full of pathos and participation by the whole family. Furthermore, in agreement with what already 
reported by De la Fuente, Souto, Caselli, Schiel (2017), the experience with nature can increase biophilia, favoring favorable perceptions, awareness, concerns and efforts towards animal welfare and conservation. Outside the agricultural contexts, some of the practices currently in use in intensive breeding involve the administration of drugs and hormones with the aim of accelerating growth and maximizing profit-please note that in the middle of last century it took about 70 days to get a chicken of the right size for the slaughterhouse while today it takes less than 50 (Zuidhof et al. 2014). A technique widely used today involves the fistulation of cows. The fistulation consists in opening a hole in the living cow's abdomen to observe the digestive processes and improve them; through this hole, in fact, the symbiotic bacteria, destroyed by the continuous use of antibiotics and fundamental for the digestion of cellulose, are introduced and reintegrated. The slaughter of animals inside slaughterhouses is carried out by observing only the most economic and not the most ethical and painless practice. According to Alves (2012) ethnozoological studies may be a valuable asset to increase our understanding of the cultural, economic, social, and traditional roles played by animals.

\section{CONCLUSIONS}

The study proved that rituals and beliefs relating to farm animals are still widespread in all the rural contexts examined. Depending on the availability of resources and the period of slaughter of the meat, long-lasting rituals are built. The administration of the interviews highlighted two different ways of understanding meat in modern society. Outside the agricultural contexts, we denoted that the establishment of intensive breeding led to the loss of rituals, turning slaughter into mere killing. In fact, in these farms, to try to cope with the growing demand of a society in continuous increase like the present one, animals are fed and treated in a way that is anything but ethical and considered exclusively as food. In the moment in which the human being, with his anthropocentric vision of the world, begins to consider and treat the animal as a machine, a disharmonic relationship is created between the latter and the human species. These brief considerations can help us understand a part of the causes that today lead many to embrace drastic and radical choices such as the exclusion of meat from the diet (although the meat rejection also has others motivations, disconnected from the loss of its ritual meaning: health reasons, sustainability reasons, anthropocentrism, a misunderstood conservation culture etc.). The old balance that was based on respect for the earth and animals has been broken and, as a result, many people express their dissent by moving away from what is easy to consider wrong, because it is no longer harmonious, no longer natural, no longer ethical. The deep split that afflicts society is perhaps born from the inner disagreement with which human beings always had to confront: the anxiety of killing against the need to feed. This duality of feelings was once smoothed and overcome thanks to the sacrificial rituals that allowed to attribute the victim a strong sacral value not only by associating the act of eating with the slaughtering, but also making it an indispensable means of communicating with deities, reconfirming the social status and re-proposing the birth of the cosmos.

Thanks to this investigation, it has been possible to verify that, even today, inserting 
a ritual component during the slaughter allows to take the animal's life away having greater awareness of what is being done and of the reason why is being done. This is the only way for man to be in harmony with nature, the only way that puts him in a state of serenity towards a drastic action like killing.

\section{ACKNOWLEDGEMENTS}

We would like to thank all the interviewees who, through many stories and witnesses, have allowed us to collect data and fundamental elements for this study. We thank Sonia De Gregorio, Carmela Chierchia and Diego Leanza for having planned the meetings with most of the interviewed sample, thus allowing a wider collection of data.

We thank Prof. Paolo Caputo (Director of Botanical Garden of the University of Naples Federico II) for useful advice, dott. Gabriele Cesarano and dott. Emanuela Berrino for the fundamental linguistic assistance in the revision phase.

\section{DATA AVAILABILITY}

The data used to support the findings of this study are available from the corresponding author upon reasonable request.

\section{CONFLICTS OF INTEREST}

The authors have no conflicts of interest to declare.

\section{CONTRIBUTION STATEMENT}

All authors wrote the first draft of the manuscript, conducted literature research and contributed to the preparation and critical revision of the manuscript. All authors read and approved the final manuscript.

\section{REFERENCES}

Alves RRN (2012) Relationships between fauna and people and the role of ethnozoology in animal conservation. Ethnobiology and Conservation 1(1):1-69 doi: 10.15451/ec2012-8-1.2-1-69.

Alves RRN Souto WMS (2015) Ethnozoology: A Brief Introduction. Ethnobiology and conservation 4(1):1-13 doi:10.15451/ec2015-14.1-1-13.

Aristotle (2002) Sulle Parti degli Animali. Carbone A (ed). Biblioteca Universale Rizzoli, Milano.

Arditi M (1825) II Fascino e l'Amuleto contro del Fascino presso gli Antichi. Stamperia Reale, Napoli.

Bailey KD (1978) Methods of Social Research. The Free Press, New York.

Basile GB (2013) Lo Cunto deli Cunti overo Lo Trattenemiento de' Peccerille, Stromboli C (ed). vol. 2, Salerno Editrice, Roma.

Beekes R, van Beek L (2010) Daphne. In: Etymological Dictionary of Greek. Brill, LeidenBoston, pp. 306-307.

Bible (2002) The Scofield Study Bible III: New King James Version. Scofield $\mathrm{Cl}$ (ed), Oxford University Press, New York.

Bradburn NM, Sudman S (1979) Improving Interview Method and Questionnaire Design. Jossey-Bass, San Francisco.

Bradburn NM (1983) Response Effects. In: Rossi PH, Wright JD, Anderson AB (eds) Handbook of Survey Research. Academic Press, London-Orlando, pp. 289-328 doi:10.1016/ C2013-0-11411-0.

Bremmer JN (2008) Modi di Comunicazione con il Divino: la Preghiera, la Divinazione e il Sacrificio nella Civiltà Greca. In: Settis S (ed) Storia Einaudi dei Greci e dei Romani. Vol. 1 (I Greci Nostri Antenati). Einaudi, Torino, pp. 239283.

Carmina (2002) Carmina Priapea. Bianchini E (ed). Collana Classici greci e latini, BUR, Milano.

Cattabiani A (2008) Calendario. Le Feste, i Miti, le Leggende e i Riti dell'Anno. Mondadori, Milano. 
Dautriat H (1970) II Questionario. Franco Angeli, Milano.

De la Fuente MFC, Souto A, Caselli CB, Schiel N (2015) People's perception on animal welfare: why does it matter? Ethnobiology and conservation 6(18):1-7 doi:10.15451/ec2017-106.18-1-7.

Frazer JG (1894) The Golden Bough: A Study in comparative Religion. Vol. 2, Macmillan and Co. and London, New York. [https://archive.org/ details/goldenboughstudy01fraz/page/n10] Accessed 14 September 2018.

Gherardini G (1854) Supplimento a' Vocabolarj Italiani. Vol. 3 (F-K), Molina PA, Milano.

Goody J (1982) Cooking, Cuisine, and Class. Cambridge University Press, Cambridge doi: 10.1017/CBO9780511607745.

Graves R (1987) New Larousse Encyclopedia of Mythology. Crescent books, New York.

Helworthy FT (1895) The Evil Eye. An Account of this Ancient \& Widespread Superstition. John Murray, London.

Labarbe J (1984) Sacrifice en Grèce. In: Poupard P (ed) Dictionnaire des Religions. Presses Universitaires de France, Paris, pp. 1500-1502.

Laum B (1924) Heiliges Geld: Eine Historische Untersuchung über den Sakralen Ursprung des Geldes. Mohr JCB, Tübingen.

Leguilloux M (1999) Sacrifices et Repas Publique dans le Sanctuaire de Poseidon à Tènos: les Analyses Aercheozoologiques. Bulletin de Corrispondence Hellenique 123:423455.

Lienhardt G (1961) Divinity and Experience: The Religion of the Dinka. Oxford University Press, Oxford.

Lincoln B, Baiocchi M (1984) Sacrificio e Creazione, Macellai e Filosofi. Studi Storici 25:859-874. [http://www.jstor.org/stable/ 20565257] Accessed 14 September 2018.

Lincoln B (1975) The Indo-European Myth of Creation. History of Religions 15:121-145.

Manganelli Rattazzi AM (1990) II Questionario. Aspetti teorici e pratici. Cleup Editrice, Padova.

Moser C, Kalton G (1977) Survey Methods in Social Investigation. Or. ed. 1958. Heinemann, London.
Nadel SF (1970) Nupe Religion: Traditional Beliefs and the Influence of Islam in a West African Chiefdom. Schocken Books, New York.

Parise NF (1984) Sacrificio e Misura del Valore nella Grecia Antica. Studi Storici 25:913-923. [http://www.jstor.org/stable/20565260] Accessed 3 April 2018.

Payne SL (1951) The art of Asking Questions. Princeton University Press, Princeton.

Pliny G II (1983) Storia Naturale. Vol. 2: Antropologia e Zoologia (Libri 7-11). Borghini A, Giannarelli E, Marcone A, Ranucci G (eds), Einaudi, Torino.

Scarpi P (1993) Sacrificio Greco. In: Filoramo G (ed) Dizionario delle Religioni. Einaudi, Torino, pp. 659-660.

Scarpi P (1994) La Religione Greca. Vol. 1 (Le Religioni Antiche). In: Filoramo G (ed) Storia delle Religioni. Laterza, Roma-Bari, pp. 283330.

Smith RW (1972) Lectures on the Religion of Semites. Or. ed. 1889. Schocken Books, New York.

Tommaseo N, Bellini B $(1861,1879)$ Dizionario della Lingua Italiana nuovamente Compilato. Unione Tipografico Editrice, Torino.

Valletta N (1787) La Cicalata sul Fascino Volgarmente detto Jettatura. s.n., Napoli.

Van Straten F (1995) Hierà Kalà: Images of Animal Sacrifice in Archaic and Classical Greece. E.J. Brill, Leiden, New York, Koln.

Vernant JP (1981) Théorie Générale du Sacrifice et mise à Mort dans la Thysia Grecque. In: Rudhardt J, Reverdin O (eds) Le Sacrifice dans l'Antiquité. Fondation Hardt, Généve, pp. 1-39.

Vernant JP (1987) Greek Religion. Vol. 6. In: Mircea E (ed) The Encyclopedia of Religion. Macmillan, New York and London, pp. 99-118.

Walter A (1871) The Life and Death of the Sublime Society of Steaks. Bradbury, London.

Zammuner VL (1998) Tecniche dell'Intervista e del Questionario. II Mulino, Bologna.

Zuidhof MJ, Schneider BL, Carney VL, Korver DR, and Robinson FE (2014) Growth, efficiency, and yield of commercial broilers from 1957, 1978, and 2005. Poultry Science 93:2970-2982 doi: 10.3382/ps.2014-04291. 
Received: 18 July 2019

Accepted: 04 April 2020

Published: 19 May 2020 